Article

\title{
An Officious Impact of Financial Innovations and ICT on Economic Evolution in China: Revealing the Substantial Role of BRI
}

\author{
Khurram Shehzad ${ }^{1, *(\mathbb{D})}$, Umer Zaman ${ }^{2, * \mathbb{D}}$, Ana Ercília José ${ }^{3}$, Emrah Koçak ${ }^{4}$ and Paulo Ferreira $^{3,5,6}$ \\ 1 School of Economics and Management, Southeast University, Nanjing 210096, China \\ 2 Endicott College of International Studies, Woosong University, Daejeon 34606, Korea \\ 3 Department of Economic Sciences and Organizations, Polytechnic Institute of Portalegre, \\ 7300-555 Portalegre, Portugal; anajose@ipportalegre.pt (A.E.J.); pferreira@ipportalegre.pt (P.F.) \\ 4 Faculty of Economics and Administrative Sciences, Erciyes University, Kayseri 38010, Turkey; \\ emrahkocak@erciyes.edu.tr \\ 5 VALORIZA-Research Center for Endogenous Resource Valorization, 7300-555 Portalegre, Portugal \\ 6 CEFAGE-UE, IIFA, University of Évora, 7000-809 Évora, Portugal \\ * Correspondence: khurramscholar64@hotmail.com or 233189917@seu.edu.cn (K.S.); \\ umerzaman@endicott.ac.kr (U.Z.)
}

Citation: Shehzad, K.; Zaman, U.; José, A.E.; Koçak, E.; Ferreira, P. An Officious Impact of Financial Innovations and ICT on Economic Evolution in China: Revealing the Substantial Role of BRI. Sustainability 2021, 13, 8962. https://doi.org /10.3390/su13168962

Academic Editor: Luigi Aldieri

Received: 2 June 2021

Accepted: 29 July 2021

Published: 10 August 2021

Publisher's Note: MDPI stays neutral with regard to jurisdictional claims in published maps and institutional affiliations.

Copyright: (c) 2021 by the authors. Licensee MDPI, Basel, Switzerland. This article is an open access article distributed under the terms and conditions of the Creative Commons Attribution (CC BY) license (https:/ / creativecommons.org/licenses/by/ $4.0 /)$.

\begin{abstract}
The Belt and Road Initiative removes regional barriers and brings communities closer together. In addition, ICT and financial innovation have helped transform the world into a big village and promoted economic growth. The study assessed the dynamic impact of ICT, economic globalization, and financial innovation on China's economic growth. The study used quarterly data from 2000 to 2019 and used the ARDL model to determine long-term and short-term consequences. The results of the study show that ICT has a positive affiliation with economic growth in China. In addition, financial innovation has also shown a direct impact on economic growth. The study shows that China's One Belt One Road project (economic globalization) has a great positive impact on its GDP. The consequences of the causality test discovered the significant unidirectional causality running from ICT and economic globalization (ECGI) to GDP. The study recommends mandatory policies related to ICT, financial innovation, and economic globalization to achieve long-term and sustainable development in China.
\end{abstract}

Keywords: sustainable development; financial innovation; ICT; globalization; OBOR; BRI; ARDL; economic growth

\section{Introduction}

Rapid developments, especially financial innovation in the financial sector, have a significant impact on dynamic economic growth, both in terms of number and value [1]. Financial modernization extends economic practices by encouraging financial inclusion, fostering financial flows in foreign trade, allowing remittances, and increasing financial performance, all of which play an essential part in economic development. Statistics from the United States [2,3] and across the world [4] indicate a close correlation between GDP, finance, and technical progress. Financial innovation in emerging countries such as China is a catalyst for growth in their financial sectors [5].

Financial innovation would accelerate economic development by promoting the expansion of financial services, financial productivity, capital investment, and effective financial intermediation, all of which are necessary for sustainable economic growth. A productive financial structure can be accomplished by implementing and disseminating technical innovations. A well-functioning financial sector, a larger range of expanded financial instruments, and product diversity are not possible without contributing to innovative technologies. Andrianova and Demetriades [6] claimed that the advent of novel financial 
assets and resources in the financial system boosts the efficiency of the banking sector and the creation of capital markets, ultimately boosting economic growth in the host country. Hence, revealing the role of financial innovations for the economy of China becomes indispensable.

With the onset of the new millennium, a new force is emerging that forms the future of the planet by eliminating regional barriers and putting society and communities closer to one another, called Information and Communication Technology (ICT) [7]. The widespread utilization of ICT has been a remarkable improvement over the last thirty years. ICT has emerged as a significant economic and societal activity market in both industrialized and emergent countries. In the second half of the 1990s, increased ICT investment boosted production and export growth in many developing and newly industrialized countries [8]. The telecommunications infrastructure is an important part of the technical development outlined in the literature. In general, one of the mechanisms by which digital technology influences progress is the way in which ICT reshapes trade methods through e-commerce, and online business promotes innovation in banking practices, triggers changes in consumer and company behavior, and strengthens experiences that ultimately promote competition and economic growth [9]. In addition, ICT raises living conditions and provides jobs for people across the world, promotes modernization, and enhances efficiency [10]. Much of the monetary exchange and foreign direct investment operations are primarily based on modern ICT streams. Vu [11] claims that ICT infrastructure facilitates operational area and advancement, improves the efficiency and level of decision-making, decreases manufacturing costs, and, more broadly, raises demand. Multinational enterprises (MNEs) should use ICT as a method to facilitate globalization. Some research suggests that high efficiency can be achieved in industries that rely heavily on ICT [12].

According to ITU (2018) reports, the use of ICT is increasing globally. The internet is expected to be used by $51.2 \%$ of the worldwide population, or 3.9 billion people, by the end of 2018. In contrast, mobile broadband and phone subscriptions were 69.3 and 107 per 100 participants, respectively. China has increased smartphone subscriptions from less than $1 \%$ to almost two-thirds. This rapid spread occurred during the period of Chinese telecommunications industry liberalization. Furthermore, since 2003, China has been the world's third-largest producer of ICT products and the world's largest exporter of ICT goods [13]. The number of internet consumers in China steadily improved from $1 \%$ to $50 \%$ from 1990 to 2015 (World Bank, 2017). Hence, this investigation analyzes the important contributions of this increasing trend of ICT into the Chinese economy.

With Japan and the newly industrialized Asian nations becoming less significant in the global economy after the 1990s, interest in East Asia decreased, but China's ascent in the global economic phase aroused attention again from eastern Asia [14]. Investments in innovative technologies and technology transfer are therefore essential from rich economies. This is particularly essential for China in the age of the knowledge economy, which is defined by the significant use of information-based technologies and technology in practically all economic activities [14]. Thus, our study extends the debate in China about the use of technological and financial innovation towards sustainable economic growth. Although most studies in China have expanded on the important contribution of ICT to China's economic growth [15-17], they have yielded various outcomes, and little is known about the position of ICT and financial innovation in China's GDP with short-and long-term prospects.

On the other hand, the Belt and Road Initiative (BRI) seeks to bring prosperity to China's underdeveloped regions, particularly its western regions, while also expanding China's opportunities to collaborate and cooperate with multiple countries along routes for improved assimilation connectivity and economic growth. The four opportunities created by the BRI are listed and evaluated, namely, a new trading path and fresh trade prospects, an integrated logistics layout, cross-border trade expansion by dropping cross-border uncertainty, and entrepreneurship in emerging countries [18], and finally, this globalized initiative boosts Chinese GDP. This initiative fosters global economic structure by deep- 
ening relationships and connecting diverse nations, increasing collaboration and shared gains, and fostering the global economic structure. BRI also draws the interest of its partner nations, continents, and the whole world [19]. BRI could increase Europe's global presence, and there will be more opportunities for China and Europe to collaborate in markets such as West Africa, the Indian Ocean, and Central Asia [20]. Trade between OBOR countries is forecast to increase by $\$ 5$ billion to $\$ 135$ billion [21]. Economic corridors have emerged in recent years as an important mechanism for regional collaboration and development in a globalized world. Therefore, economic globalization can be recognized as the main factor that makes major contributions to economic development. The economic component of globalization illustrates the size of cross-border economic activity, consumption, and revenue flows concerning GDP, as well as the effect of constraints on trade and capital operations (Cherkashina, 2011). Moreover, economic globalization will eliminate tariffs and taxes and add flexibility to financial innovation and commerce that can accelerate economic growth [22]. As a result, China has a surprising level of foreign direct investment (FDI) inflow, and economic growth can be achieved [23]. As a result, these powerful forces have increased the importance of financial innovations, ICT, and globalization to GDP $[24,25]$. In view of the above discussion, we construct a close link amid financial innovation, globalization, ICT, and economic growth. This study contributes to the literature as follows: first, this investigation evaluates the imperious impact of financial innovations specifically for the economic growth in China after considering the role of OBOR. Second, we ascertain that how ICT affects the economic growth in China after taking into account the impact of financial innovations and economic globalization.

The remaining part of the study is organized as follows: Section 2 nominates the review of recent literature, Section 3 defines the methodological framework, Section 4 exposed the outcomes of the study, and Section 5 summarized the conclusion and policy recommendations.

\section{Literature Review}

The conventional economic view of innovation is that it improves the efficiency of financial products and services [26,27], accelerates the financial growth cycle [28], improves capital investment and allocation mechanisms [29,30], and improves financial effectiveness in the financial sector. Additionally, financial growth is influenced by financial institutions' competition because improved payment systems facilitate domestic and foreign trade [31]. Financial growth introduces and commercializes innovative financial instruments, organizations, and technologies into the monetary system [32]. Schumpeter and Backhaus [33] emphasized the critical role of the fine-functioning financial intermediaries in economic growth and innovation. Uddin, Kyophilavong et al. [34] have demonstrated that financial growth by strengthening the banking system will contribute to economic development and thus help to mitigate poverty. The growth of the financial sector helps citizens to have access to more institutional investment credit [35].

Financial innovation is an important aspect of economic movement; for example, improved financial technologies and modified payment systems have caused operational vicissitudes to the financial sector [36,37], innovative products and features for current financial products, and fresh financial institutions [38-40]. Changes in government policies and shifting societal attitudes have also taken place [41,42]. Some studies also suggest that financial inclusion has a positive impact on macroeconomic metrics such as economic stability as measured by aggregate demand variance [43], growth [44], and consumption and production [45].

ICT contributes to economic prosperity. ICT is described by the Department for International Development as "technologies that facilitate contact and the processing and dissemination of knowledge through electronic means." Additionally, scholars at the University of Manchester Institute for Development Policy and Management define it as "an electronic means of processing, encoding, storing, and disseminating content." In general, ICT relates to the use of automated and computer-based systems for the purpose 
of gaining access to and interacting with the outside world. Numerous researches on the interaction between ICT and economic development have been undertaken during the last two decades. The bulk of research indicates that ICT has a positive effect on economic development [11,46,47]. Singapore, Hong Kong, South Korea, China, and Taiwan have risen to the level of high-income developing countries, showing that ICT has a robust and rising capacity. Each of these findings establishes a direct causal connection between ICT and economic development. On the other side, various studies suggest that the impact of information and communication technologies on economic development remains unclear or doubtful [48].

Niebel [49] examines the effect of ICTs on economic development in developing, emerging, and industrialized countries. ICT's average performance elasticity is greater than the compensation share for ICT factors, meaning that ICT services generate excess returns. Regressions on subsamples of developing, emerging, and developed countries show that there are no statistically important variations in the elasticity of ICT production between these three countries. As per the findings, developing and emerging economies that do not benefit more than developed economies from ICT investment [50] have found consistent outcomes with the GMM framework approach, especially with regard to mobile phones Bahrini and Qaffas [51], which looked at the impact of ICTs on economic development in the Middle East and North Africa (MENA) area as a whole. According to the study's findings, information and networking technologies, such as cell phones, internet use, and broadband penetration, are critical components of economic growth. Indeed, the results indicate that cell phones have had the biggest positive impact on economic development and that internet and wireless use are major drivers of economic growth in developed countries.

Myovella, Karacuka [52] analyzed the relation of digitization to economic development for 41 sub-Saharan African (SSA) countries from 2006 to 2016 relative to 33 OECD countries using the GMM model. The findings indicate that digitization leads positively to economic development in both classes of countries. The sway of broadband internet on SSA is marginal relative to OECD nations, while the impact of mobile phones on SSA is higher than the OECD equivalent. These findings are especially interesting, considering that lower modern technologies provide more potential in the slightest developed countries, as the further potential for enhancement David and Grobler [53] has shown that smartphone telecommunications are rising faster than other telecommunications indices and that ICT infiltration benefits Africa's economic growth and development. As a result, the research proposes that Africa simultaneously invests in fixed-line and internet access telecommunications in order to fully leverage the optimal momentum of ICT infiltration for economic growth and development. This analysis analyses an 11-year panel dataset covering 41 SSAs from 2006 to 2016.

Lam and Shiu [54] find evidence of a bidirectional association between actual GDP and telecommunications development, and that telecommunication has a greater impact in countries that have liberalized this sector. The data were obtained from 2000 to 2017 for ten Middle Eastern and twenty-four OECD countries, using the OLS and GMM techniques. The findings indicate that ICT is favorably connected with monetary development in both forms of countries. OLS is being used in the BRICS economies between 2000 and 2014. The empirical findings indicate that there is a long-term elasticity among ICT and economic development, implying that ICT adds favorably to economic progress. The results on longterm output fluctuations suggest that, while together, FDI and globalization have a longterm impact on economic progress [55]. Some scholars say that globalization is a malignant phenomenon [56]. The world has seen outstanding globalization of the international economy in the form of national and international trade and finance networks over the last three decades. The association between globalization and economic development has been extensively studied in a number of ways. Others use the latest technique as a panel data methodology to investigate interaction amid globalization and economic progress. In this esteem, the research directed by [57] explores that the rise in trade transparency and overseas investment has exhibited greater economic growth. Sbia, Shahbaz [58] investigate 
the relationship between some facets of economic progress and globalization, as well as the relationship between globalization and FDI growth. The utmost topical and inclusive research of the connection between globalization and economic progress was directed by [59]. It demonstrates globalization has a noteworthy impact on economic development and is beneficial for growth.

Jorgenson and $\mathrm{Vu}[60]$ mention that the world economy is entering a New Economic Order in this fast-changing climate, in which emerging Asia, led by two fast-growing giant economies, will have much greater impacts on the global economy. China will eclipse the United States as the world economy's second-biggest theme over the next decade. One of the most notable economic trends in 2010 was China's overtaking of Japan as the world's second-largest economy in terms of exchange rates. China surpassed Japan in terms of purchasing power parities more than five years ago, according to the World Bank's 2005 International Comparison Program.

The study of [47] evaluated the long-term connections among ICT, economic growth, and energy consumption for the nation of Japan. The study investigated the energy demand function and production function through the ARDL approach, including the ICT as an external factor. The study could not find a significant role of ICT for the production function; nevertheless, the study revealed an imperious role of ICT for the energy demand function in Japan. The findings nominated that ICT imperatively reduced energy consumption but did not upsurge economic growth in Japan. Another research looked at the link between renewable energy use and GDP per capita in 25 European nations. However, this study ignores ICT. The data also reveal a stronger link between renewable energy use and economic development in high-income nations than in low-income countries $[61,62]$ examined the impact of ICT, oil prices, and electricity prices on the usage of electricity for the industry of South Korea through a logistic growth model. The investigation documented that ICT investments significantly reduced the usage of electricity in some of the manufacturing industries but not the major portion of the manufacturing sector. Additionally, the investigation reported that ICT investments in the service industry amplify the electricity consumption in South Korea.

The study used the GMM model to analyze the impact of ICT in the OPEC nations. The consequences of the investigation ravel that ICT possesses an encouraging role for the economy of OPEC nations. Specifically, the study stated that the coefficient of ICT investment has a positive impact on the GDP of OPEC countries. Moreover, the examination nominated that FDI has also a positive relationship with GDP in OPEC nations $[63,64]$ employed the ARDL methodology to ascertain the impact of ICT on environmental sustainability in Pakistan after controlling the role of economic growth. The investigation stated that the usage of ICT is safe for the environment of Pakistan; however, the manufacturing of ICT tools significantly damages the environmental sustainability in Pakistan. Moreover, the investigation discovered that importing ICT play a significant role in the economy and environmental excellence in Pakistan.

\section{ICT-Financial Innovation-Sustainable Economic Growth Nexus in China}

Currently, the study on China's economic issues has become a representative topic for understanding global rising economies. The Chinese economy is growing steadily, and changing the economic structure is critical for sustaining this growth $[65,66]$. China has grown rapidly over 35 years. The yearly growth rate has recently decreased and is expected to reach $5 \%$ by 2030; that strong economic growth may be sustained in the future is examined in this study [14]. In doing so, the study considers future growth rates. The paper stresses that increasing capital and labor quality through technological advancements may help economic growth. Thus, new technology investments and advanced economic technology transfer are critical for sustainable growth [14]. For sustained economic growth, technological breakthroughs need to be created more rapidly. Additionally, their influence on resource efficiency must be considerably increased. $[67,68]$ explores fintech's viability as a platform for sustainable economic growth and as a catalyst for the fourth industrial 
revolution. That is, as a platform business, fintech has the potential to improve overall national economic performance. Due to the fact that the majority of firms in the fintech industry rely on innovation via the integration of finance and information technology, we believe that fintech has the potential to kickstart the fourth industrial revolution, therefore aiding in sustainable development.

Ref. [69] study the influence of ICT, financial development, and economic expansion on Malaysian power consumption; quarter-frequency data from 1990 to 2015 is used. A cointegration method with structural break is used to evaluate the long-run connection. An analysis of ICT, financial development, and economic growth as economic tools for sustainable development. Ref. [70] examines if innovation policies are achieving their objectives of sustainability, social inclusion, and economic growth in the context of planning. The research examines if and how the EU's self-determined sustainable development, social inclusion, and economic growth objectives are addressed and accomplished. The results imply a faulty funneling procedure. Firstly, a focus is placed on innovation in order to unblock opposition systematically to the development and implementation of innovation in the name of competitiveness, job creation, and economic growth. Secondly, the notion of innovation is very unambiguously defined and understood strictly as efficiency and behavioral change, digitalization, and smart technology when translated into urban design.

With increased development and convergence of financial and ICT platforms, digital financial systems emerged, opening up new opportunities to close the wealth gap between the "haves" and "have-nots" in the developing world. The empirical findings show that careful co-Curation of ICT infrastructure development, financial inclusion efforts, and economic growth methods are required to achieve sustainable economic development [71]. The study of [72] examines the impact of financial globalization, urbanization, eco-innovation, and economic growth on the G7 nations' ecological footprints, using yearly data from 1980 to 2016. The study recommended G7 nations should support eco-innovation initiatives, promote sustainable urbanization, and accelerate economic growth rates by transforming their production and consumption processes. The above-presented literature revealed that ICT and financial innovations play an imperious role in sustainable economic growth in various nations. However, the role of these factors in the Chinese economy is still undiscovered. Moreover, the impact of the newly developed project of China, i.e., OBOR is completely ignored in previous studies. Hence, this investigation explores the foremost impact of ICT, financial innovations, and OBOR on the economic progress in China.

\section{Data and Methodology}

\subsection{Data}

The investigation used that quarter data from the period of 2006Q4 to 2019Q4. The main objective of this examination is to analyze the implication of ICT and financial technologies after considering the impact of OBOR in China. Therefore, the study employed the ratio of Automated Teller Machines (ATM) per 100,000 persons for the nomination of financial innovation (FI). The study engaged the ratio of mobile subscriptions per 100 people for the representation of ICT. Ref. [73] also used the same factor for the nomination of ICT in Pakistan. We utilized gross domestic product (GDP) per capita (constant 2010 US\$), for the indication of economic growth in China [74]. Moreover, to represent the one belt one road project impact, we applied an index of economic globalization established by the KOFG. Ref. [75] also applied this index to nominate globalization in 139 countries. The data utilized in this investigation is downloaded from the database of the World Bank.

\subsection{Methodology}

This investigation used the log form of the data to avoid the multicollinearity issues; thus, the linear connection among them can be structured as follows,

$$
\ln G D P_{t}=\zeta_{0}+\zeta_{1} \ln I C T_{t}+\zeta_{2} \ln F I_{t}+\zeta_{3} \ln E C G I_{t}+\varepsilon_{t}
$$


here, $\ln$ indicates the natural $\log$ and $t$ nominates the time. However, $\zeta_{0}, \zeta_{1}, \zeta_{2}, \zeta_{3}$, are the parameters of independent factors. Furthermore, ICT describes information and communication technology, FI proposes financial innovations, and ECGI stands for the economic globalization index. Additionally, GDP stipulates the Gross Domestic Product value in China. We used the Autoregressive Distributed Lag (ARDL) model, which was introduced by [76] to calculate the harmony between variables. The ARDL can be engaged whichever variable is stationary at the level, first difference, or has different integration order [77], and it is appropriate for undersized data. Furthermore, in the ARDL model, the dependency factors are explained by its past values and previous values of other external factors engaged in the study [78]. We analyze the ARDL cointegration as follows:

$$
\begin{gathered}
\Delta \ln G D P_{t}=\psi_{0}+\psi_{1} \sum_{i=1}^{p} \Delta \ln G D P_{t-1}+\psi_{2} \sum_{i=1}^{p} \Delta \ln I C T_{t-1}+\psi_{3} \sum_{i=1}^{p} \Delta \ln F I_{t-1}+\psi_{4} \sum_{i=1}^{p} \Delta \ln E C G I_{t-1}+\varphi_{1} \ln G D P_{t-i} \\
+\varphi_{2} \ln I C T_{t-i}+\varphi_{3} \ln F I_{t-i}+\varphi_{4} \ln E C G I_{t-i}+\mu_{t} \\
\Delta \ln I C T_{t}=\psi_{0}+\psi_{1} \sum_{i=1}^{p} \Delta \ln I C T_{t-1}+\psi_{2} \sum_{i=1}^{p} \Delta \ln G D P_{t-1}+\psi_{3} \sum_{i=1}^{p} \Delta \ln F I_{t-1}+\psi_{4} \sum_{i=1}^{p} \Delta \ln E C G I_{t-1}+\varphi_{1} \ln I C T_{t-i} \\
+\varphi_{2} \ln G D P_{t-i}+\varphi_{3} \ln F I_{t-i}+\varphi_{4} \ln E C G I_{t-i}+\mu_{t} \\
\Delta \ln F I_{t}=\psi_{0}+\psi_{1} \sum_{i=1}^{p} \Delta \ln F I_{t-1}+\psi_{2} \sum_{i=1}^{p} \Delta \ln G D P_{t-1}+\psi_{3} \sum_{i=1}^{p} \Delta \ln I C T_{t-1}+\psi_{4} \sum_{i=1}^{p} \Delta \ln E C G I_{t-1}+\varphi_{1} \ln F I_{t-i} \\
+\varphi_{2} \ln G D P_{t-i}+\varphi_{3} \ln I C T_{t-i}+\varphi_{4} \ln E C G I_{t-i}+\mu_{t} \\
\Delta \ln E C G I_{t}=\psi_{0}+\psi_{1} \sum_{i=1}^{p} \Delta \ln E C G I_{t-1}+\psi_{2} \sum_{i=1}^{p} \Delta \ln G D P_{t-1}+\psi_{3} \sum_{i=1}^{p} \Delta \ln I C T_{t-1}+\psi_{4} \sum_{i=1}^{p} \Delta \ln F I_{t-1}+\varphi_{1} \ln E C G I_{t-i} \\
+\varphi_{2} \ln G D P_{t-i}+\varphi_{3} \ln I C T_{t-i}+\varphi_{4} \ln F I_{t-i}+\mu_{t}
\end{gathered}
$$

here $i$ designates the lag standards and $\Delta$ identifies the first difference operative factor, $\psi_{1}-\psi_{8}$ signifies the short-term coefficients and $\varphi_{1}-\varphi_{8}$ are the long-term factors, while $\mu_{t}$ denotes the residual factor. The ARDL model is based on F-statistics to find the enduring association among the underlying factors. Thus, the study tested the null hypothesis that there is no integration against the alternative hypothesis that there is significant cointegration among the factors [76] quantified the upper critical bounds (UCBs) and lower critical bounds (LCBs) to ascertain the suitability of the model employed in the study. If the predicted coefficient of F-statistics is greater than UCBs, it implies that there is a significant cointegration among the underlying factors. Conversely, when the F-statistics is lesser than LCBs then it means cointegration among the variables does not exist. Moreover, if the F-statistics falls between the LCBs and UCBs, then it specified that findings are inconclusive. If the long-run co-integration relationship between variables is dogged, then we ascertain the long-run and short-run causality amid the study factors. If there are no signs of an association between the factors evaluated in the investigation, then vector Autoregression (VAR) will be used to determine Granger causality. However, if the investigation finds the confirmation of the co-integration relationship, the Granger causality will be subtracted by a period of lag error correction (ECTt-1) [79].

$$
\begin{aligned}
\Delta \ln G D P_{t} & =\psi_{0}+\psi_{1} \sum_{i=1}^{p} \Delta \ln G D P_{t-1}+\psi_{2} \sum_{i=1}^{p} \Delta \ln I C T_{t-1}+\psi_{3} \sum_{i=1}^{p} \Delta \ln F I_{t-1}+\psi_{4} \sum_{i=1}^{p} \Delta \ln E C G I_{t-1}+\gamma_{1} E C T_{t-1}+\mu_{t} \\
\Delta \ln I C T_{t} & =\psi_{0}+\psi_{1} \sum_{i=1}^{p} \Delta \ln I C T_{t-1}+\psi_{2} \sum_{i=1}^{p} \Delta \ln G D P_{t-1}+\psi_{3} \sum_{i=1}^{p} \Delta \ln F I_{t-1}+\psi_{4} \sum_{i=1}^{p} \Delta \ln E C G I_{t-1}+\gamma_{2} E C T_{t-1}+\mu_{t} \\
\Delta \ln F I_{t} & =\psi_{0}+\psi_{1} \sum_{i=1}^{p} \Delta \ln F I_{t-1}+\psi_{2} \sum_{i=1}^{p} \Delta \ln G D P_{t-1}+\psi_{3} \sum_{i=1}^{p} \Delta \ln I C T_{t-1}+\psi_{4} \sum_{i=1}^{p} \Delta \ln E C G I_{t-1}+\gamma_{3} E C T_{t-1}+\mu_{t} \\
\Delta \ln E C G I_{t} & =\psi_{0}+\psi_{1} \sum_{i=1}^{p} \Delta \ln E C G I_{t-1}+\psi_{2} \sum_{i=1}^{p} \Delta \ln G D P_{t-1}+\psi_{3} \sum_{i=1}^{p} \Delta \ln I C T_{t-1}+\psi_{4} \sum_{i=1}^{p} \Delta \ln F I_{t-1}+\gamma_{3} E C T_{t-1}+\mu_{t}
\end{aligned}
$$


Here $E C T_{t-1}$ symbolizes the error-correction parameter, which computes the rapidity of modification of our dependent factor for achieving long-term symmetry. The research uses serial correlation and heteroskedasticity tests to evaluate the aptness of the underlying model. In addition, we employed the cumulative sum of recursive residuals (CUSUM) and its square (CUSUMSQ) tests [80] to analyze the stability of the model.

\section{Results and Discussion}

We report the descriptive statistics in Table 1 of the complete data set, which indicates that except ICT all the variables are normally distributed. Moreover, these statistics indicated that GDP has the highest mean value following the ICT, ECGI, and FI. Table 2 reports the correlation analysis, the ICT and Financial Innovation (FI) showed a positive association with GDP while the economic globalization index (ECGI) showed a negative association.

Table 1. Descriptive statistics.

\begin{tabular}{ccccc}
\hline & GDP & ICT & FI & ECGI \\
\hline Mean & 8.584244 & 4.305450 & 3.650284 & 3.832334 \\
Median & 8.615163 & 4.433573 & 3.738229 & 3.819903 \\
Maximum & 9.018518 & 4.790487 & 4.575937 & 3.957540 \\
Minimum & 8.027048 & 3.539457 & 2.263911 & 3.773795 \\
Std. Dev. & 0.286733 & 0.358701 & 0.743140 & 0.046386 \\
Skewness & -0.262851 & -0.612582 & -0.328591 & 1.386334 \\
Kurtosis & 1.910400 & 2.194177 & 1.777633 & 4.158618 \\
Jarque-Bera & 3.232097 & 4.748746 & 4.253403 & 19.94143 \\
Probability & 0.198682 & 0.093073 & 0.119230 & 0.000047 \\
\hline
\end{tabular}

Source: Author's calculation.

Table 2. Correlation test.

\begin{tabular}{ccccc}
\hline & GDP & ICT & FI & ECGI \\
\hline GDP & 1.000000 & & & \\
& - & & & \\
ICT & 0.987996 & 1.000000 & & \\
& 0.0000 & - & 1.000000 & \\
FI & 0.995144 & 0.983953 & - & 1.000000 \\
& 0.0000 & 0.0000 & -0.849880 & - \\
ECGI & -0.828353 & -0.864479 & 0.0000 & \\
& 0.0000 & 0.0000 & & \\
\hline
\end{tabular}

Source: Author's calculation.

To examine the unit root specification of the employed factors we applied the Augmented Dickey-Fuller (ADF) [2] and Phillips and Perron [81] test (PP). The outcomes of the unit root test were reported in Table 3. The outcomes of ADF showed that maximum factors out of the underlying variables, i.e., GDP, FI, and ECGI were stationery at I(1), while the results of PP demonstrate the mixed level of integration of the used variables, i.e., $\mathrm{I}(0)$ and $\mathrm{I}(1)$; however, none of the variables is contained within at $\mathrm{I}(2)$. Hence, it permits us to apply the ARDL method to conclude the cointegration association between the variables by using the bound test approach [76]. Table 4 nominates the findings of the ARDL bound test, implying that the variables used in the study have significant long-run cointegration among them. Hence, the short-run and long-run effects of study variables can be ascertained through the ARDL approach. 
Table 3. Unit Root Evaluation.

\begin{tabular}{ccccc}
\hline Variables & \multicolumn{2}{c}{ ADF } & \multicolumn{2}{c}{ PP } \\
\hline & Level & 1st Diff & Level & 1st Diff \\
& T-STAT & T-STAT & T-STAT & T-STAT \\
\hline GDP & -2.395600 & $-2.603586^{*}$ & $-8.730599^{* * *}$ & $-2.854659^{* *}$ \\
ICT & -1.915613 & 0.000484 & $-4.790170^{* * *}$ & -1.370568 \\
FI & $-2.675314^{*}$ & 0.073535 & $-3.577427^{* * *}$ & -1.757131 \\
ECGI & -2.399503 & $-3.289367^{* *}$ & -2.017004 & $-3.210621^{* *}$ \\
\hline
\end{tabular}

Source: Author's calculation. Note: ${ }^{*}, * *$, and ${ }^{* * *}$ nominates the $10 \%, 5 \%$, and $1 \%$ levels of significance.

Table 4. ARDL bound test results (cointegration).

\begin{tabular}{cccc}
\hline Model & I(0) & I(1) & Critical Bound Value \\
\hline FGDP (GDP/Yt, ICT, FI, ECGI) & 2.37 & 3.2 & $10 \%$ \\
F-Stat 5.9122 & 2.79 & 3.67 & $5 \%$ \\
Lags ARDL(5, 0, 4, 4) & 3.15 & 4.08 & $2.50 \%$ \\
& 3.65 & 4.66 & $1 \%$ \\
\hline
\end{tabular}

Source: Author's calculation.

\subsection{ARDL Reckoning}

Table 5 summarizes the study's short and long-run ARDL model findings. The results of the long-run ARDL model show that in the long run, there is a momentous direct association between ICT and GDP in China. This means the ICT technology will be strengthened, and as a result, economic development will accelerate. Consequently, It is expressed that ICT facilitates access to and distribution of knowledge, which boosts trade and economic activities, raises per capita GDP, lowers costs, and broadens consumer penetration [82]. The effect of ICT market liberalization, the reduction of mobile and broadband investment licenses has been shown to be important for economic development, especially in China. In this respect, several longitudinal studies such as $[83,84]$ measure the encouraging impact of technologies on economic improvements. The majority of topical research reveals the powerful and optimistic association between GDP and ICT. Stanley, Doucouliagos [85] discovered that factors indicating the ICT such as landlines, internet subscribers, and mobile phone users had an encouraging affiliation with economic growth in advanced and emerging nations. Trade operations are an effective tool for China, which is attempting to promote them through the use of new technologies. In order to boost regional import and export operations, China has implemented policies that make possible and promote the application of ICT instruments into global trade [86]. 
Table 5. ARDL Long Run results.

\begin{tabular}{ccccc}
\hline Variable & Coefficient & Std. Error & t-Statistic & $p$ Values \\
\hline Long-run & & & & \\
ICT & 0.431557 & 0.036781 & 11.73323 & 0.0000 \\
FI & 0.238508 & 0.022701 & 10.50652 & 0.0000 \\
ECGI & 0.647267 & 0.160030 & 4.044666 & 0.0003 \\
C & 3.280583 & 0.706720 & 4.641981 & 0.0001 \\
Short-run & & & & \\
D(GDP(-1)) & 0.315039 & 0.135954 & 2.317253 & 0.0273 \\
D(GDP(-2)) & -0.054952 & 0.145715 & -0.377121 & 0.7087 \\
D(GDP(-3)) & -0.231270 & 0.129997 & -1.779044 & 0.0850 \\
D(GDP(-4)) & 0.361007 & 0.088104 & 4.097515 & 0.0003 \\
D(FI) & 0.063859 & 0.010732 & 5.950630 & 0.0000 \\
D(FI(-1)) & -0.007659 & 0.017457 & -0.438719 & 0.6639 \\
D(FI(-2)) & 0.015256 & 0.017313 & 0.881192 & 0.3850 \\
D(FI(-3)) & 0.045997 & 0.014837 & 3.100213 & 0.0041 \\
D(ECGI) & 0.216290 & 0.024586 & 8.797138 & 0.0000 \\
D(ECGI(-1)) & -0.044919 & 0.043481 & -1.033062 & 0.3096 \\
D(ECGI(-2)) & 0.037420 & 0.043684 & 0.856622 & 0.3982 \\
D(ECGI(-3)) & 0.109188 & 0.035932 & 3.038727 & 0.0048 \\
ECT $(t-1$ & 0.077531 & 0.013420 & 5.777167 & 0.0000 \\
R-squared & 0.953893 & & & \\
Adj.R-squared & 0.938084 & & & \\
Durbin-Watson & 1.610786 & & & \\
\hline Source: Author'scalculation & & &
\end{tabular}
Source: Author's calculation.

The outcomes revealed that a one-unit increase in financial innovations expressively surges the economic growth by 0.238 units in the long run. Moreover, in the short run, the third lag of FI exposed a positive impact on FI. However, the first and second lag remains insignificant. Hence, these findings suggest that the advent of financial innovation performs a crucial role in economic development. The study of Silve and Plekhanov [87] indicated that financial innovation has a significant role in building high-class financial organization, efficient mobilization of economic resources, and well-organized financial intermediation which replicates the economic development. Wachter [88], meanwhile, concluded that financial innovation adds to economies by consolidation and integration of financial markets through new and innovative institutions as well as with financial services. According to Chou [89], financial innovation would bring significant variations to the financial structure that will amplify financial performance and increase the population's saving tendency by providing new and better financial assets; this would ultimately help to build up resources and thereby fuel economic growth. Thus, financial innovations not only leverage economic wealth by channeling across the world but also stimulate economic growth in the course of competent payment systems and intermediation procedures. Such results are consistent with Mwinzi [41], Qamruzzaman and Jianguo [90], and Beck, Senbet [91].

The results show that economic globalization has an optimistic and major relationship with economic growth. Particularly, one unit boost in ECGI brings 0.64 units amplification in economic growth in the long run. In addition, a one-unit increase in ECGI increases the 0.19 unit economic growth in the short run. These verdicts signified that economic growth will be boosted by an increase in opening the border for international trade and foreign direct investment. This can be possible because of the fact that ICT facilitates the public to exchange product information at each area of the globe. Conversely, globalization has reduced the distance among different states and brought the people closer. Therefore, ICT is a prime agent of economic globalization in China. The study confirmed that One Belt One Road and Silk Road projects imperatively boost economic growth. The results are matched with the work of $[92,93]$. The results nominate that disequilibrium occurred because of shocks in the underlying variables in the previous quarter will be adjusted with 
the speed of 0.077 units in the next quarter. Further, the value of R-squared (0.953) and adjusted R-square (0.938) stated that $95 \%$ of variations in the economic growth are due to the factors employed in this study, and $93.8 \%$ variations are due to significant factors among them. The outcomes of the short-run and long-run causality tests are given in Table 6. The findings unravel that ICT and ECGI have significant unidirectional casualty affiliation with GDP in the short run. Additionally, significant causality is moving from ICT towards FI in the short run. The investigation stated that there was significant long-run causality is transferring from (1) ICT, ECGI, and FI to GDP; (2) GDP, ICT, and FI to ECGI; (3) GDP, ICT, and ECGI to FI.

Table 6. Short-run and Long-run Granger causality fallouts.

\begin{tabular}{|c|c|c|c|c|c|}
\hline Independent & & Short-' & nalysis & & Long-Run \\
\hline Variable & GDP & ICT & ECGI & FI & ECTt-1 \\
\hline GDP & - & 0.33838 & 0.00551 & 2.7914 & {$[-3.31167]$ * } \\
\hline ICT & $8.2765 *$ & - & 0.00105 & $4.3719 * *$ & {$[-0.06096]$} \\
\hline ECGI & $5.7669^{* *}$ & 0.35983 & - & 0.9603 & {$[-2.30014] * *$} \\
\hline FI & 0.0814 & 1.89124 & 0.01634 & - & {$[-3.23474] *$} \\
\hline
\end{tabular}

Source: Author's calculation. Note: ${ }^{*}$ and ${ }^{* *}$ nominates the $1 \%$ and $5 \%$ levels of significance. Note2: The values in the bracket denote the T-statistics.

\subsection{Diagnostic Test Results}

The outcomes of the diagnostic test are given in Table 7. We used the BreuschGodfrey test to evaluate the serial correlation and heteroscedasticity in the residuals of the model and found that residuals are free from heteroscedasticity and serial correlation. Moreover, the Ramsey-RESET test specified that there was no misspecification in the model. Further, the cumulative sum of recursive residuals (CUSUM) and its square (CUSUMSQ) plots (Figure 1) are within the $5 \%$ level of significance, inferring that model is stable. Consequently, these verdicts show that our model perfectly fits the study.

Table 7. Outcomes of the diagnostic models.

\begin{tabular}{ccccccc}
\hline \multicolumn{3}{c}{ Breusch-Godfrey Heteroskedasticity Results } & \multicolumn{2}{c}{ Breusch-Godfrey Serial Correlation LM Results } \\
\hline F-statistic & 1.699855 & Prob. & 0.1003 & F-statistic & 0.933020 & Prob. \\
Obs * & 22.43197 & Prob. & 0.1298 & Obs * & 2.901891 & Prob. \\
R-squared & Ramsey RESET results & & & & 0.4049 \\
& 0.533190 & Prob. & 0.5978 & & & \\
T-statistic & 0.284291 & Prob. & 0.5978 & & & \\
F-statistic & 0.2343 & \\
\hline
\end{tabular}

Source: Author's calculation. * Here Obs nominate the number of observations. 

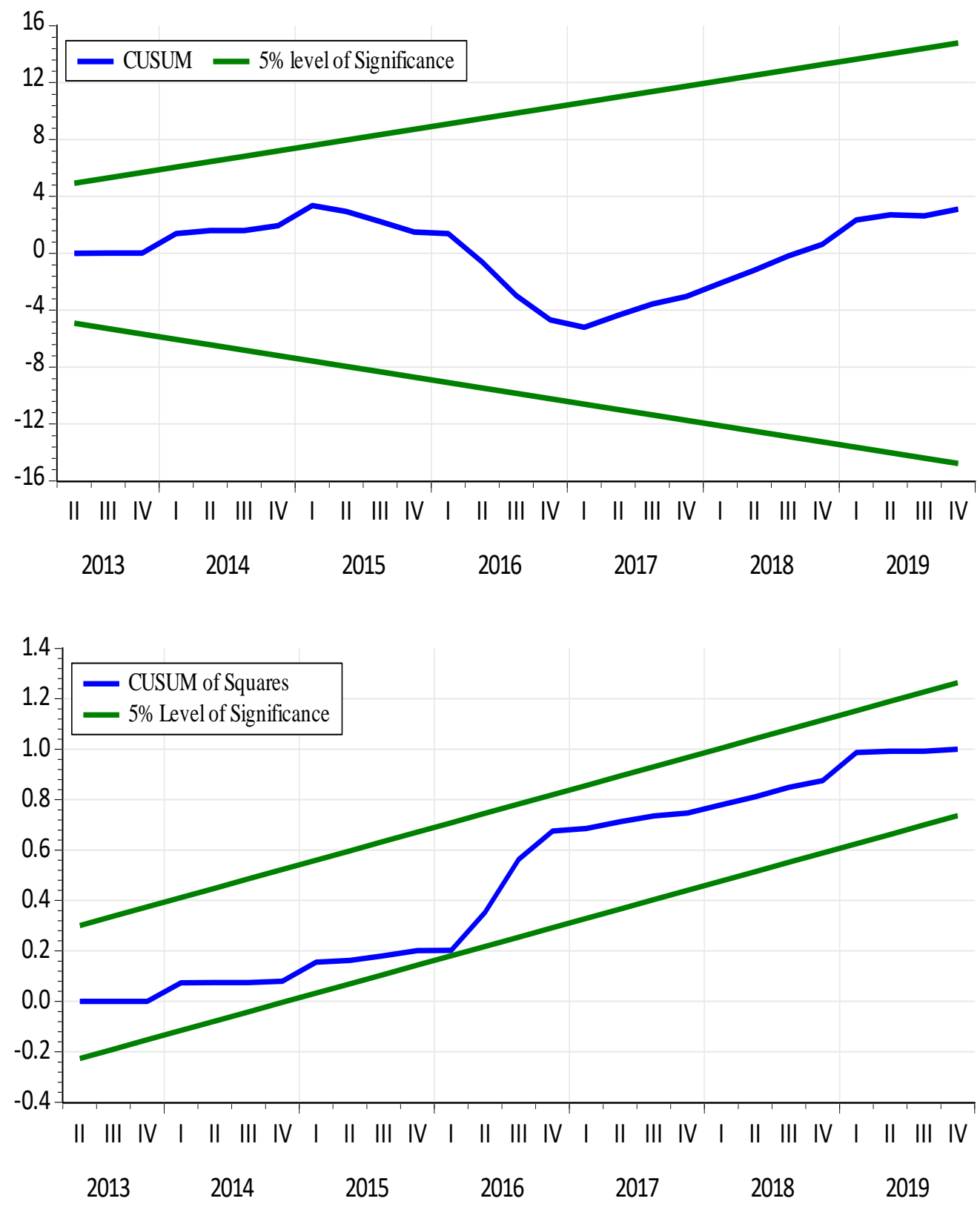

Figure 1. Plots of CUSUM and CUSUMSQ at 5\% level of significance.

\section{Concluding Remarks and Policy Recommendation}

The study analyzes the effect of ICT, economic globalization, and financial innovation on economic growth in China. In the empirical literature, very few studies were found that investigate the effect of ICT, economic globalization, and financial innovation specifically for the homeland of China. The study used quarterly data from 2000 to 2019 and the ARDL model was applied. The key contribution of this research is to assess the importance of ICT for China's economic development. Furthermore, the study determines the dominant position of financial innovation for sustainable development in China. The survey considers the impact of the recently developed OBOR project on economic progress in China. Hence this research sheds light on the superior role of ICT and financial technologies, considering the OBOR project as a key indicator of economic globalization, essential elements for sustainable development. The main outcomes of the study confirmed that the ICT revealed an encouraging and significant effect on GDP. Ref. [60] stated that ICT and globalization have sped up the economic growth of China and India. Ref. [49] also mentioned that ICT has a positive association with economic growth in 59 countries. The study also concluded 
that financial innovation has a positive and significant effect on economic growth. Ref. [89] argued that financial innovation appreciably improves the efficiency of financial institutions by providing various kinds of financial services and products, which leads to economic growth. Moreover, Ref. [90] used the two different proxies to measure financial innovation and found that it has feedback causality with economic growth in Bangladesh. We control the effect of economic globalization and found a positive and significant effect on GDP. Ref. [94] analyzed the data from 1970 to 2008 for the ASEAN nations and discovered that economic globalization has a direct affiliation with economic growth. Additionally, Ref. [95] also originated that globalization has a significant and positive relationship in CEE countries from 1990 to 2009. Further, Ref. [96] found unidirectional causality running from globalization, economic globalization, and social globalization to economic growth in OECD nations. Moreover, Ref. [97] found evidence of the positive relationship of globalization with economic growth in Pakistan from 1970 to 2014.

\section{Policy Implications}

Based on the aforementioned results, it is possible to make straight-forward policy recommendations: to encourage economic growth, careful attention must be given to the advancement of the ICT sector, e.g., Immediate approach to ICT and its entire network should be made reachable to the general public, ICT, R\&D centers should be enhanced, and the public should be educated in the use of ICT. Policymakers should correlate ICT with additional tools, i.e., investment in critical infrastructure and human capital while noting that ICT possesses a greater rate of return compared to these alternative tools due to external partners (including information spell-over networks). Advanced ICT gadgets such as big data, cloud computing, and the Internet of Things (IoT) are actually overcoming the effects of obstruction. Policy-makers should also ensure that the successful usage of these new ICT tools in China can mitigate the effects of negative externalities. The country's legislation should also be updated in such a way as to promote ICT in general, including third generation, fourth generation, and fifth-generation licenses, prevent the monopoly on the industry and raise the number of users without data congestion [98]. The study showed that financial innovation is an important mechanism for boosting economic growth in China, with the causality flowing from financial development to economic growth. The policy advice is that better financial markets, financial instruments, and payment mechanisms are required for economic growth in China, both in the short and long term. The emphasis of China's short-and long-term financial policies should be on improving the efficiency of the financial sector through the production and execution of sound financial reforms to strengthen the financial sector. Diversification of banking services and expand financial inclusion, such as the use of mobile banking, internet banking, automated teller machines (ATMs), and rural banking, are projected to incorporate additional remittancerecipient households in China from the informal financial sector into the formal financial system for sustainable development. The findings of the study also show that the promotion of globalization is very important for economic development. China is the most common example of being able to create the greatest progressive change by globalization over the last three decades. Our findings suggest that the more China is globalized, the higher their growth rates are due to fewer trade restrictions. The study documented a significant unidirectional causality connection of ICT and ECGI with GDP in the short run. In addition, a long-run causality relationship running from ICT, ECGI, and FI to GDP were discovered. The findings of the study indicate significant proposed policies, such as the need for physical infrastructures such as landlines and cell phone improvements, and the need to expand internet connectivity to ordinary citizens who lived in rustic districts turn out to be a crucial element of the universal community, in particular. Policy-makers can synchronize technical expertise in the field, including quick access to data and safe and efficient connectivity. 
Author Contributions: Conceptualization, K.S. and E.K.; methodology, K.S.; software, E.K.; validation, U.Z., A.E.J. and P.F.; formal analysis, A.E.J.; investigation, U.Z.; resources, U.Z.; data curation, E.K.; writing - original draft preparation, K.S., U.Z. and E.K; writing—review and editing, U.Z., A.E.J. and P.F.; visualization, U.Z.; supervision, E.K.; project administration, U.Z. All authors have read and agreed to the published version of the manuscript.

Funding: This research received no external funding.

Institutional Review Board Statement: Not applicable.

Informed Consent Statement: Not applicable.

Data Availability Statement: The data used in this study can be found from the database of World Bank.

Acknowledgments: We are thankful to the Editor and two anonymous reviewers for their great kind guidance to improve the article.

Conflicts of Interest: The authors declare no conflict of interest.

\section{References}

1. Błach, J. Financial innovations and their role in the modern financial system-identification and systematization of the problem. e-Finans. Financ. Internet Q. 2011, 7, 13-26.

2. Chava, S.; Oettl, A.; Subramanian, A.; Subramanian, K.V. Banking deregulation and innovation. J. Financ. Econ. 2013, 109, 759-774. [CrossRef]

3. Amore, M.D.; Schneider, C.; Žaldokas, A. Credit supply and corporate innovation. J. Financ. Econ. 2013, 109, 835-855. [CrossRef]

4. Beck, T.; Chen, T.; Lin, C.; Song, F.M. Financial innovation: The bright and the dark sides. J. Bank. Financ. 2016, 72, 28-51. [CrossRef]

5. Ndako, U.B. Financial Development, Economic Growth and Stock Market Volatility: EVIDENCE from NIGERIA and South Africa; University of Leicester: Leicester, UK, 2010.

6. Andrianova, S.; Demetriades, P. Sources and effectiveness of financial development: What we know and what we need to know. In Financial Development, Institutions, Growth and Poverty Reduction; Springer: Berlin/Heidelberg, Germany, 2008 ; pp. 10-37.

7. Nasir, S.; Kalirajan, K. Information and communication technology-enabled modern services export performances of Asian economies. Asian Dev. Rev. 2016, 33, 1-27. [CrossRef]

8. Lee, S.H.; Levendis, J.; Gutierrez, L. Telecommunications and economic growth: An empirical analysis of sub-Saharan Africa. Appl. Econ. 2012, 44, 461-469. [CrossRef]

9. Bojnec, Š.; Fertő, I. Broadband availability and economic growth. Ind. Manag. Data Syst. 2012, 112. [CrossRef]

10. Mago, S.; Mago, S. Information and communications technologies (ICTs) and livelihoods enhancement in agro-rural communities in Zimbabwe: Connections using the capabilities approach. J. Commun. 2015, 6, 93-103. [CrossRef]

11. Vu, K.M. ICT as a source of economic growth in the information age: Empirical evidence from the 1996-2005 period. Telecommun Policy 2011, 35, 357-372. [CrossRef]

12. Luo, Y.; $\mathrm{Bu}$, J. How valuable is information and communication technology? A study of emerging economy enterprises. J. World Bus. 2016, 51, 200-211. [CrossRef]

13. Ning, L. China's Rise in the World ICT Industry: Industrial Strategies and the Catch-Up Development Model; Routledge: Oxfordshire, UK, 2009.

14. Akkemik, K.A. Rapid economic growth and its sustainability in China. Percept. J. Int. Aff. 2015, 20, 133-158.

15. Zhang, L.; Gao, J. Exploring the effects of international tourism on China's economic growth, energy consumption and environmental pollution: Evidence from a regional panel analysis. Renew. Sustain. Energy Rev. 2016, 53, 225-234. [CrossRef]

16. Heshmati, A.; Yang, W. Contribution of ICT to the Chinese economic growth. Ratio Work. Pap. 2006, 91, 2006.

17. Sun, L.; Zheng, H.; Ren, R. The Contribution of ICT to China's Economic Growth: Evidence from Industrial Panel Data Analysis. J. World Econ. 2012, 2, 3-25.

18. Lee, H.L.; Shen, Z.-J.M. Supply chain and logistics innovations with the Belt and Road Initiative. J. Manag. Sci. Eng. 2020, 5, 77-86. [CrossRef]

19. Wu, X.; Chen, G. Energy use by Chinese economy: A systems cross-scale input-output analysis. Energy Policy 2017, 108, 81-90. [CrossRef]

20. Haggai, K. One Belt One Road strategy in China and economic development in the concerning countries. World J. Soc. Sci. Humanit. 2016, 2, 10-14.

21. Enderwick, P. The economic growth and development effects of China's One Belt, One Road Initiative. Strateg. Chang. 2018, 27, 447-454. [CrossRef]

22. Mishkin, F.S. Globalization, macroeconomic performance, and monetary policy. J. Money Credit. Bank. 2009, 41, 187-196. [CrossRef] 
23. Glushkova, S.; Lomakina, O.; Sakulyeva, T. The economy of developing countries in the context of globalization: Global supply chain management. Int. J. Supply Chain. Manag. 2019, 8, 876-884.

24. Drori, G.S. Globalization and technology divides: Bifurcation of policy between the "digital divide" and the "innovation divide". Sociol. Inq. 2010, 80, 63-91. [CrossRef]

25. Rohman, I.K. The globalization and stagnation of the ICT sectors in European countries: An input-output analysis. Telecommun Policy 2013, 37, 387-399. [CrossRef]

26. Schrieder, G.; Heidhues, F. Reaching the poor through financial innovations. Q. J. Int. Agric. 1995, 34, 132.

27. McGuire, P.B.; Conroy, J.D. Fostering Financial Innovation for the Poor: The Policy and Regulatory Environment; United Nations Development Programme (UNDP): New York, NY, USA, 2013.

28. Ozcan, Y.A. Health Care Benchmarking and Performance Evaluation; Springer: Berlin/Heidelberg, Germany, 2008.

29. Uddin, K.M.K.; Rahman, M.M.; Quaosar, G.A.A. Causality between exchange rate and economic growth in Bangladesh. Eur. Sci. J. 2014, 10, 857-7881.

30. Uddin, G.S.; Shahbaz, M.; Arouri, M.; Teulon, F. Financial development and poverty reduction nexus: A cointegration and causality analysis in Bangladesh. Econ. Model. 2014, 36, 405-412. [CrossRef]

31. Sabandi, M.; Noviani, L. The effects of trade liberalization, financial development and economic crisis on economic growth in Indonesia. J. Econ. Sustain. Dev. 2015, 6, 120-128.

32. Sood, V.; Ranjan, P. Financial innovation in India: An empirical study. J. Econ. Bus. Rev. 2015, 10, 1-20.

33. Schumpeter, J.; Backhaus, U. The theory of economic development. In Joseph Alois Schumpeter; Springer: Berlin/Heidelberg, Germany, 2003; pp. 61-116.

34. Uddin, G.S.; Kyophilavong, P.; Sydee, N. The casual nexus of banking sector development and poverty reduction. Int. J. Econ. Financ. Issues 2012, 2, 304.

35. Uddin, M.G.S.; Chakraborty, L. International trade, financial development and economic growth nexus in Bangladesh: Empirical evidence from time series approach. Proceedings of International Finance Conference. pp. 3-5. Available online: https: / / www.researchgate.net/publication/312578291_International_trade_financial_development_and_economic_growth_ nexus_in_Bangladesh_Empirical_evidence_from_time_series_approach (accessed on 1 August 2021).

36. Boot, A.W.; Marinč, M. Financial innovation: Economic growth versus instability in bank-based versus financial market driven economies. Int. J. Bus. Commer. 2010, 2, 1-32.

37. Michalopulos, S.; Laeven, L.; Levine, R. Financial Innovation and Endogenous Growth; Department of Economics, Tufts Univercity: Medford, MA, USA, 2010.

38. Sekhar, S.; Gudimetla, V. Theorems and theories of financial innovation: Models and mechanism perspective. Financ. Quant. Anal. FQA 2013, 1, 26-29. [CrossRef]

39. Simiyu, R.S.; Ndiang'ui, P.N.; Ngugi, C.C. Effect of financial innovations and operationalization on market size in commercial banks: A case study of Equity Bank, Eldoret branch. Int. J. Bus. Soc. Sci. 2014, 5, 227-249.

40. Odularu, G.O.; Okunrinboye, O.A. Modeling the impact of financial innovation on the demand for money in Nigeria. Afr. J. Bus. Manag. 2009, 3, 39-51.

41. Mwinzi, D.M. The Effect of Financial Innovation on Economic Growth in Kenya; University of Nairobi: Nairobi, Kenya, 2014.

42. Chin, M.; Chou, Y. Financial Innovations and Endogenous Growth. 2001. Available online: https://fbe.unimelb.edu.au/_data/ assets /pdf_file/0011/805943/804.pdf (accessed on 13 May 2021).

43. Mehrotra, A.; Yetman, J. Financial inclusion-issues for central banks. BIS Quarterly Review March. 2015. Available online: https:/ / www.bis.org/publ/qtrpdf/r_qt1503h.pdf (accessed on 10 May 2021).

44. Dabla-Norris, M.E.; Ji, Y.; Townsend, R.; Unsal, M.F. Identifying Constraints to Financial Inclusion and their Impact on GDP and Inequality: A Structural Framework for Policy; International Monetary Fund: Washington, DC, USA, 2015.

45. Buera, F.J.; Kaboski, J.P.; Shin, Y. The macroeconomics of microfinance. Rev. Econ. Stud. 2021, 88, 126-161. [CrossRef]

46. Erumban, A.A.; Das, D.K. Information and communication technology and economic growth in India. Telecommun. Policy 2016, 40, 412-431. [CrossRef]

47. Ishida, H. The effect of ICT development on economic growth and energy consumption in Japan. Telemat. Inform. 2015, 32, 79-88. [CrossRef]

48. Veeramacheneni, B.; Ekanayake, E.; Vogel, R. Information technology and economic growth: A causal analysis. Southwest. Econ. Rev. 2007, 34, 75-88.

49. Niebel, T. ICT and economic growth-Comparing developing, emerging and developed countries. World Dev. 2018, 104, 197-211. [CrossRef]

50. Haftu, G.G. Information communications technology and economic growth in Sub-Saharan Africa: A panel data approach. Telecommun. Policy 2019, 43, 88-99. [CrossRef]

51. Bahrini, R.; Qaffas, A.A. Impact of information and communication technology on economic growth: Evidence from developing countries. Economies 2019, 7, 21. [CrossRef]

52. Myovella, G.; Karacuka, M.; Haucap, J. Digitalization and economic growth: A comparative analysis of Sub-Saharan Africa and OECD economies. Telecommun. Policy 2020, 44, 101856. [CrossRef]

53. David, O.O.; Grobler, W. Information and communication technology penetration level as an impetus for economic growth and development in Africa. Econ. Res. Ekon. Istraživanja 2020, 33, 1394-1418. [CrossRef] 
54. Lam, P.-L.; Shiu, A. Economic growth, telecommunications development and productivity growth of the telecommunications sector: Evidence around the world. Telecommun. Policy 2010, 34, 185-199. [CrossRef]

55. Latif, Z.; Latif, S.; Ximei, L.; Pathan, Z.H.; Salam, S.; Jianqiu, Z. The dynamics of ICT, foreign direct investment, globalization and economic growth: Panel estimation robust to heterogeneity and cross-sectional dependence. Telemat. Inform. 2018, 35, 318-328. [CrossRef]

56. Das, D.K. Another perspective on globalization. J. Int. Trade Law Policy 2010, 9. [CrossRef]

57. Dreher, A.; Sturm, J.-E.; Ursprung, H.W. The impact of globalization on the composition of government expenditures: Evidence from panel data. Public Choice 2008, 134, 263-292. [CrossRef]

58. Sbia, R.; Shahbaz, M.; Hamdi, H. A contribution of foreign direct investment, clean energy, trade openness, carbon emissions and economic growth to energy demand in UAE. Econ. Model. 2014, 36, 191-197. [CrossRef]

59. Adhikary, B.K. FDI, trade openness, capital formation, and economic growth in Bangladesh: A linkage analysis. Int. J. Bus. Manag. 2011, 6, 16. [CrossRef]

60. Jorgenson, D.W.; Vu, K.M. The ICT revolution, world economic growth, and policy issues. Telecommun. Policy 2016, 40, 383-397. [CrossRef]

61. Ntanos, S.; Skordoulis, M.; Kyriakopoulos, G.; Arabatzis, G.; Chalikias, M.; Galatsidas, S.; Batzios, A.; Katsarou, A. Renewable energy and economic growth: Evidence from European countries. Sustainability 2018, 10, 2626. [CrossRef]

62. Cho, Y.; Lee, J.; Kim, T.-Y. The impact of ICT investment and energy price on industrial electricity demand: Dynamic growth model approach. Energy Policy 2007, 35, 4730-4738. [CrossRef]

63. Nasab, E.H.; Aghaei, M. The effect of ICT on economic growth: Further evidence. Int. Bull. Bus. Adm. 2009, 5, 46-56.

64. Shehzad, K.; Xiaoxing, L.; Sarfraz, M.; Zulfiqar, M. Signifying the imperative nexus between climate change and information and communication technology development: A case from Pakistan. Environ. Sci. Pollut. Res. 2020, 27, 30502-30517. [CrossRef]

65. Chen, F.-W.; Fu, L.-W.; Wang, K.; Tsai, S.-B.; Su, C.-H. The influence of entrepreneurship and social networks on economic growth-from a sustainable innovation perspective. Sustainability 2018, 10, 2510. [CrossRef]

66. Liu, W.; Cai, Z. International Comparison of China's Economic Growth in the New Era and Industrial Structure Upgrading. Manag. World 2018, 1, 16-24.

67. Stamm, A.; Dantas, E.; Fischer, D.; Ganguly, S.; Rennkamp, B. Sustainability-Oriented Innovation Systems: Towards Decoupling Economic Growth from Environmental Pressures; Discussion Paper; 2009; Available online: https://www.files.ethz.ch/isn/111302/2 009-20e.pdf (accessed on 13 May 2021).

68. Shin, Y.J.; Choi, Y. Feasibility of the FinTech industry as an innovation platform for sustainable economic growth in Korea. Sustainability 2019, 11, 5351. [CrossRef]

69. Solarin, S.A.; Shahbaz, M.; Khan, H.N.; Razali, R.B. ICT, financial development, economic growth and electricity consumption: New evidence from Malaysia. Glob. Bus. Rev. 2019, 22, 941-962. [CrossRef]

70. von Schönfeld, K.C.; Ferreira, A. Urban planning and european innovation policy: Achieving sustainability, social inclusion, and economic growth? Sustainability 2021, 13, 1137. [CrossRef]

71. Pradhan, R.P.; Arvin, M.B.; Nair, M.S.; Hall, J.H.; Bennett, S.E. Sustainable economic development in India: The dynamics between financial inclusion, ICT development, and economic growth. Technol. Forecast. Soc. Chang. 2021, 169, 120758. [CrossRef]

72. Ahmad, M.; Jiang, P.; Murshed, M.; Shehzad, K.; Akram, R.; Cui, L.; Khan, Z. Modelling the dynamic linkages between ecoinnovation, urbanization, economic growth and ecological footprints for G7 countries: Does financial globalization matter? Sustain. Cities Soc. 2021, 70, 102881. [CrossRef]

73. Shehzad, K.; Xiaoxing, L.; Sarfraz, M. Envisaging the asymmetrical association among FDI, ICT, and climate change: A case from developing country. Carbon Manag. 2021, 12, 123-137. [CrossRef]

74. Zeraibi, A.; Balsalobre-Lorente, D.; Shehzad, K. Examining the Asymmetric Nexus between Energy Consumption, Technological Innovation, and Economic Growth; Does Energy Consumption and Technology Boost Economic Development? Sustainability 2020, 12, 8867. [CrossRef]

75. Gözgör, G.; Can, M. Causal linkages among the product diversification of exports, economic globalization and economic growth. Rev. Dev. Econ. 2017, 21, 888-908. [CrossRef]

76. Pesaran, M.H.; Shin, Y.; Smith, R.J. Bounds testing approaches to the analysis of level relationships. J. Appl. Econom. 2001, 16, 289-326. [CrossRef]

77. Ahmad, M.; Khan, Z.; Ur Rahman, Z.; Khan, S. Does financial development asymmetrically affect $\mathrm{CO}_{2}$ emissions in China? An application of the nonlinear autoregressive distributed lag (NARDL) model. Carbon Manag. 2018, 9, 631-644. [CrossRef]

78. Cherni, A.; Jouini, S.E. An ARDL approach to the $\mathrm{CO}_{2}$ emissions, renewable energy and economic growth nexus: Tunisian evidence. Int. J. Hydrogen Energy 2017, 42, 29056-29066. [CrossRef]

79. Engle, R.F.; Granger, C.W. Co-integration and error correction: Representation, estimation, and testing. Econom. J. Econom. Soc. 1987, 55, 251-276. [CrossRef]

80. Brown, R.L.; Durbin, J.; Evans, J.M. Techniques for testing the constancy of regression relationships over time. J. R. Stat. Soc. Ser. B 1975, 37, 149-163. [CrossRef]

81. Phillips, P.C.; Perron, P. Testing for a unit root in time series regression. Biometrika 1988, 75, 335-346. [CrossRef]

82. Ilegbinosa, I.A.; Micheal, A.; Watson, S.I. Domestic investment and economic growth in Nigeria from 1970-2013: An econometric analysis. Can. Soc. Sci. 2015, 11, 70-79. 
83. Stanley, T.D.; Doucouliagos, H.; Giles, M.; Heckemeyer, J.H.; Johnston, R.J.; Laroche, P.; Nelson, J.P.; Paldam, M.; Poot, J.; Pugh, G. Meta-analysis of economics research reporting guidelines. J. Econ. Surv. 2013, 27, 390-394. [CrossRef]

84. Stanley, T.D.; Doucouliagos, H. Meta-regression approximations to reduce publication selection bias. Res. Synth. Methods 2014, 5, 60-78. [CrossRef]

85. Stanley, T.D.; Doucouliagos, H.; Steel, P. Does ICT generate economic growth? A meta-regression analysis. J. Econ. Surv. 2018, 32, 705-726. [CrossRef]

86. Shehzad, K.; Liu, X.; Rauf, A.; Arif, M.; Mazhar, S.; Sohail, N.; Amin, W. Revolutionising tourism development in China: An effective role of ICT and Western Silk Road project. Asia Pac. J. Tour. Res. 2019, 24, 965-977. [CrossRef]

87. Silve, F.; Plekhanov, A. Institutions, innovation and growth: Cross-country evidence. 2015, p. 177. Available online: https: / / papers.ssrn.com/sol3/papers.cfm?abstract_id=3119688 (accessed on 1 August 2021). [CrossRef]

88. Wachter, J.A. Comment on:" Can financial innovation help to explain the reduced volatility of economic activity?". J. Monet. Econ. 2006, 53, 151-154. [CrossRef]

89. Chou, Y.K. Modeling financial innovation and economic growth: Why the financial sector matters to the real economy. J. Econ. Educ. 2007, 38, 78-90. [CrossRef]

90. Qamruzzaman, M.; Jianguo, W. Financial innovation and economic growth in Bangladesh. Financ. Innov. 2017, 3, 1-24. [CrossRef]

91. Beck, T.; Senbet, L.; Simbanegavi, W. Financial inclusion and innovation in Africa: An overview. J. Afr. Econ. 2015, 24, i3-i11. [CrossRef]

92. Toivanen, H. Knowledge economy and globalization. In Directions in Development-Information and Communication Technologies; 2014; pp. 131-147. Available online: https://www.researchgate.net/publication/263523275_Knowledge_Economy_and_Globalization (accessed on 13 May 2021).

93. Zembylas, M.; Vrasidas, C. Globalization, information and communication technologies, and the prospect of a 'global village': Promises of inclusion or electronic colonization? J. Curric. Stud. 2005, 37, 65-83. [CrossRef]

94. Ying, Y.-H.; Chang, K.; Lee, C.-H. The impact of globalization on economic growth. Rom. J. Econ. Forecast. 2014, 17, 25-34.

95. Gurgul, H.; Lach, Ł. Globalization and economic growth: Evidence from two decades of transition in CEE. Econ. Model. 2014, 36, 99-107. [CrossRef]

96. Chang, C.-P.; Lee, C.-C. Globalization and economic growth: A political economy analysis for OECD countries. Glob. Econ. Rev. 2010, 39, 151-173. [CrossRef]

97. Hassan, S.T.; Xia, E.; Huang, J.; Khan, N.H.; Iqbal, K. Natural resources, globalization, and economic growth: Evidence from Pakistan. Environ. Sci. Pollut. Res. 2019, 26, 15527-15534. [CrossRef] [PubMed]

98. Waqar, J. Impact of ICT on GDP Per Worker: A New Approach Using Confidence in Justice System as an Instrument: Evidence from 41 European Countries. 2015, pp. 1996-2010. Available online: https://www.diva-portal.org/smash/get/diva2:931181/FULLTEXT0 1.pdf (accessed on 13 May 2021). 